The Poetics of Demur: Lowell and Frost

Author(s): Robert G. Twombly

Source: College English, Vol. 38, No. 4 (Dec., 1976), pp. 373-378+383-392

Published by: National Council of Teachers of English

Stable URL: http://www.jstor.org/stable/376422

Accessed: 09-08-2016 17:01 UTC

\title{
REFERENCES
}

Linked references are available on JSTOR for this article:

http://www.jstor.org/stable/376422?seq=1\&cid=pdf-reference\#references_tab_contents You may need to log in to JSTOR to access the linked references.

Your use of the JSTOR archive indicates your acceptance of the Terms \& Conditions of Use, available at

http://about.jstor.org/terms

JSTOR is a not-for-profit service that helps scholars, researchers, and students discover, use, and build upon a wide range of content in a trusted digital archive. We use information technology and tools to increase productivity and facilitate new forms of scholarship. For more information about JSTOR, please contact support@jstor.org.

National Council of Teachers of English is collaborating with JSTOR to digitize, preserve and extend access to College English 


\section{The Poetics of Demur: Lowell and Frost}

Robert Lowlel writes "confessional" poetry. That descriptive epithet, on the surface, means no more than that the incidents in many of his poems are the incidents in his life (deaths of relatives, visits to New Hampshire, sojourns in psychiatric wards, political enterprise), and that the "I" of his poems accordingly stands bare, unshielded by any evident fiction, or by much intervening wittiness. The word "confessional" carries at least the potential for disparagement; so that two reader-friends have felt they could sum up their response to Lowell by saying, "I don't like confessional poetry." If their aesthetic judgement was at fault in this (and I believe it was), their cranky and reductive petulance was a not-wholly-invalid dramatic response to the kind of personal emotional intrusion that some of Lowell's poetry, in its confessionalism, makes upon the reader's sympathies. Their objection would have been, I think, (had they taken the pains to frame it) that the heavy presence of Lowell himself is disconcerting, and indeed a hindrance to the appreciation of such aesthetically distillable qualities as pattern and form, theme and image and metrical grace.

"Waking in the Blue," for instance, is almost an elegantly bitter metaphysical lament at the puniness and bravery ("bravado" is the word in the poem) of insane men who still feel the lure and dare of the Platonic dream. Their delusions genial yet consuming, old men "ossified young," their pathos is in not feeling the approach of death. But if we are to regard them in a metaphysical light, wistful exemplars of the self-deception in the soul of Everyman, then what is called for at the close of the poem is poise, a sustained and subtle balance between an all-tooeasy scorn at the pomps of human imagination, and an all-too-sentimental pity for its frailty. Lowell avoids the scorn, and he avoids the pity; but he avoids as well the balance, the metaphysical steady view of paradox. Instead he intrudes, personally, querulously, with the kind of self-directed sarcasm that produces tension and embarrassment but never humor;

After a hearty New England breakfast,

I weigh two hundred pounds

this morning. Cock of the walk,

Robert G. Twombly, Associate Professor of English at The University of Texas (Austin), was educated at Amberst and Yale. His scholarly interests are focused on the Reformation, and on English Baroque poetry. He also teaches courses in contemporary poetry and criticism.

College English

Vol. 38, No. 4 • December 1976 
I strut in my turtle-necked French sailor's jersey

before the metal shaving mirrors, and see the shaky future grow familiar

in the pinched, indigenous faces

of these thoroughbred mental cases,

twice my age and half my weight.

We are all old-timers,

each of us holds a locked razor. ${ }^{1}$

Suicide talk is a conversation spoiler at the easiest of times; when it is used to close off so essentially public a communication as a poem, and when the grinningly overwrought rhymer of faces and cases is the poet in his or her own person, the fastidious reader may feel put upon. ${ }^{2}$ Here, she/he may feel, is more poetic self-indulgence, and more poetic self, indeed, than the proprieties of art (as Keats and Eliot understood art) will allow. Instead of resting in the contemplation of a universal, the reader has the grim jitters for the fate of this individual writer. Instead of feeling released toward the sudden freedom of new intuitions, the reader is left locked (like the razor) into the uncomfortable obligation somehow or other to protect the poet's life. We are not free to interpret the poem; at least not in any conventional way. We are not free to toy critically, for instance, with the poem's animal imagery, and pronounce on the Jansenism of the way Lowell levels downward Man's false little dignity. If "each of us holds a locked razor" might on one level be an aphorism on the condition of Man, it is in any case here and now a shamefully whispered hint of Robert Lowell's self-disgust. In other words, it is not autobiography alone that makes the designation "confessional" appropriate to this poetry. It is as well the reader's frequent and uncomfortable sense that she/he is privy to the banal obscenities of a most un"poetic" soul, and has incurred against his/her choice and expectations a strange sense of responsibility toward that soul.

The aim of what follows will be to develop an argument to the effect that the poetics of Robert Lowell, and of Robert Frost (and by implication of some others as well), is a poetics of stringent social decorum, of constraints thrown upon the reader not to respond in certain ways. It is a poetics of affect rather than of form, in which closure is achieved not by the precise intersection of form and theme, but by a tacit agreement between poet and audience that their social interaction cannot by its own rules proceed any further. However it is a more narrow poetics even than that; for the rules governing the cases I am interested in are the rules of silence, not of acclaim, and by a gesture of demur or of annoyance or of deep confidentiality the speaker enjoins his audience to strict forebearance.

Robert Frost's poetry, lacking such unmistakably autobiographical signals as

\footnotetext{
${ }^{1}$ From Life Studies (Farrar, Straus \& Giroux, 1959), p. 82. Copyright (C) 1959 by Robert Lowell. Reprinted by permission of Farrar, Straus \& Giroux.

2The Editor has substituted "he/she" for "he" in certain places, in accordance with the Guidelines for Nonsexist Use of Language in NCTE Publications. Mr. Twombly adds: "Though this author does not believe such usage (as 'she/he') will or should prevail, he acknowledges its temporary and limited heuristic value for an age like ours, struggling however clumsily toward self-awareness and (in the sense of this essay) 'love'."
} 
some of Lowell's poetry possesses, has not to my knowledge been called confessional. Nevertheless from an affective angle the vulnerability or the gruffness or the self-biting irony or the hasty demur in Frost's manner achieves a poetic closure sometimes very close to Lowell's. In one of its senses, the word "confessional" applies to both men's poetry; for both men are self-centered in their griefs or shames. We, their audience, feel an obligation to observe the rules of discretion. A testy reaction to Frost finds him presuming upon our benevolence and well-mannered respect in order to indulge his own splenetic clowning. A better, more appropriate reaction to Frost extends to the splenetic clown the protections and privacies that Lowell at his most confessional demands of us. It is an odd, new thing to suggest that there can be an aesthetics of the social act, particularly of the act of withdrawal or restraint or demurring silence, on the part of the audience. How can a work of poetry complete itself in an audience's discreet foregoing of further curiosity? But then, even more basically, how can a work of poetry complete itself in anything the audience does of a social or ritual nature?

The answer to that must precede any further exploring into the affective dynamics of confessional poetry. However, the answer can be, and has been given in the form of an even more vigorous rhetorical question contra: How can a work of poetry, or any other act of communication, complete itself in any way except in an act of mutual response, or ritual, between the poet and his/her audience? In critical shorthand, the assumption that poetry is a form of two-way communication is contained in the designating of a poem as a performance. The word suggests at the verv least that to pay attention to a poem is to pay attention to a creative process, originating and concluding within some sort of time frame, and involving the implicit imaginative interaction of a performer and his audience. In a moment I shall want to question the peripheral connotations of the words "performance" and "performer." For the moment it may help to give the most rapid survey of the relevant argument in aesthetics.

We are taught early to distinguish, in the realm of communication, form and matter. And paradoxically (from a Platonic standpoint) we are taught that it is the matter that matters, not the form. The prejudice passes over, with further paradoxical inversions, into the way we have taught ourselves to think about poetry, where it has been form that matters. In either case, though, we have taught ourselves to look for something pure and lasting, unaffected by the whimsical and momentary. Since ordinary communication in our technological society seems to consist of pure information on the one side (abstract, precise, preservable, and transportable) and of implication and affective nuance on the other (ambiguous, untranslatable), we accordingly have drawn the line in poetic language between pure evocations of archetypal experience on the one side, and "personal feeling" or "personal intent" on the other. The dualistic model is weak in two notable respects. As the phenomenologists in general have challenged the notion that there can be any such thing as pure information, free of metaphorical nuance, so Burke has shown that even our "archetypal experience" is of our own devising, and hence not easy to use as a standard by which to dismiss the merely 
personal. ${ }^{3}$ If that is one front, in the attack, the other belongs to the social scientists. To R. D. Laing virtually every communication (and, in the extremity of his insight, every silence as well) is "political," in the sense that it implies an ethical positioning, relative to each other, of the two parties involved. When someone speaks to you, and most clearly when someone questions you, she/he is making either an explicit or an implicit demand on you which you may or may not feel capable of fulfilling. There is no way he/she can wholly avoid making that demand, even if she/he wants to; hence the need on the part of those who feel emotionally most hard-pressed to retreat into a world of total non-communication. ${ }^{4}$ A similar analysis, represented for instance by Bateson, points out that every communication presumes some set of conditions making the communication meaningful. Hence the very saying (or writing) of a word is an invitation or a demand to the addressee to assent to those conditions that make the word meaningful. We cannot speak without making the invitation or demand. Nor can we attend to another's speaking without acquiescing to his demand. A web of implied intent, challenge, and constraint surrounds every communicative act. ${ }^{5}$ In the insight of Erving Goffman this web of implications constitutes the major portion of the import of most communicative acts, and consists of signals in which a pattern of mutual obligations is negotiated (perhaps lopsidedly) between the actors. ${ }^{6}$ What develops almost inevitably, then, out of any consideration of the communicative aspects of poetry is on the one hand a conviction in the abstract that a poem, within the experiential realm, is an event in which the implicit addressee is called upon to feel and respond to the intent of the addressor, and on the other hand a suspicion on the particular level that we should heed carefully those intimations within ourselves as to our relationship with the poetic performer. We, the actual audience, are always under some discernible constraint to feel and respond in the manner of the implicit audience. ${ }^{7}$ In the case of Lowell and Frost there is frequently no fictive addressee, and consequently the pressure on us (as actual audience) to identify with the implicit audience is so immediate as to escape our conscious notice, even among readers who resent the experience.

3Throughout his Philosoplyy of Literary Form (revised edition, New York: Vintage Books, 1957) Kenneth Burke hunts out the complex relationships between symbolic meaning and symbolic function, those relationships always a reflection of the artist's most personal and not necessarily successful struggle to externalize his own anxieties. Implicitly, then, the fundamental artistic motive is the project of the psyche to gain and hold control, in whatever terms are culturally convenient, over its most deep and troubling fear. Manifest form is invented and reinvented to fulfill the private and incoherent need. Elsewhere Burke acknowledges his debt to Freud for this model, of which perhaps the best recent discussion is in Ernest Becker, The Denial of Deatb (New York: Free Press, 1973).

${ }^{4}$ Cf. Ronald David Laing, The Politics of Experience (New York: Pantheon Books, 1967), pp. 3 ff., 50-67, 68-90.

${ }_{5}$ Gregory Bateson, Steps to an Ecology of Mind (New York: Chandler, 1972), esp. pp. 177-200.

${ }^{6}$ Erving Goffman, Interaction Ritual (Garden City, N. Y.: Anchor Books, 1967), esp. ch. 1, “On Face Work," pp. 5-45.

7Walker Gibson, Tough, Sweet and Stuffy (Bloomington, Ind.: Indiana University Press, 1966), esp. pp. 15-42. Cf. also Wolfgang Iser, The Implied Reader (Baltimore: Johns Hopkins University Press, 1974). 
If a poem, then, is a performance, that is, a virtual event involving a performer and an audience engaged in a processive relationship, we still need to define the event, or describe tentatively what it may consist of. Richard Bauman has most helpfully observed that for his own purposes a performance should be defined as a situated event, possessing the kind of clear and acknowledged boundaries that enable a participant to feel that she/he is clearly inside it. ${ }^{8}$ Bauman's sense of performance is in this regard at least analogous to Huizinga's sense of the ordinary game which takes place within a marked-off time and space, and to Turner's and Eliade's (not Goffman's) sense of ritual which also imposes its special scenario upon the otherwise ordinary spatial and temporal landscape. ${ }^{9}$ Despite the helpfulness of these analogies (and they may be more than analogies), there is a difficulty that arises when we try to apply the word "performance" to the poems I am here chiefly interested in. This difficulty, and its resolution, constitute the main concern of this paper.

If the performer-poet is like a game-player or like a priest, or if in fact she/he is like any protagonist or participant in game, feast, revel, or rite, then his/her frame will be ours, and we will be caught up together in the heady fellowship of the event. Call that fellowship festivitas, since that is a fair designation for what we often feel the performer has won for him/herself and the audience. By festivitas I do not mean merely a feeling of communal joy, at least not in a superficial sense. ${ }^{10}$ The state of being caught up to which I refer can emerge from solemnity, or terror, or folly, or hilarity, or any combination. But in any event to be caught up in it is to be released from the narrow economies of privacy or of mere friendship into a general folly, or general awe, or general vulnerability, and most importantly general trust. The performer brings this about, or helps to bring it about, by relinquishing his/her own privacy. He/she dares step onto a high place, a stage, dais, tightrope or scaffold, or some rhetorical equivalent, such as a boast or hyperbolical declaration. He/she releases us from our ordinary obligations to protect his/her "face." He/she may wear a mask to do this, or may make his/her face mask-like. He may speak prepared or conventional lines, or make a series of prepared or conventional gestures. Be she/he clown, preacher, poet, tennis player, or tragic hero, she/he performs within a set or framework of rules. Accordingly she/he performs with a kind of abandon. The tragedian abandons him or herself to a representation of fate, the evangelist preacher abandons him or herself to "the spirit of the Word," the bard to his/her song, the gladiator to violence, the fool to his folly. Each in his/her abandon symbolizes and effects the at least temporary abandon of his/her onlookers. We the audience join the performance event through some act (a cry, a prayer, a dance, applause,

8Richard Bauman, "Verbal Act as Performance," American Antbropologist, 1975, 77:290-311. 9Johan Huizinga, Homo Ludens: A Study of the Play Element in Culture (Boston: Beacon Press, 1955). pp. 1-27; and Victor Turner, Dramas, Fields, and Metaphors (Ithaca, N.Y.: Cornell University Press, 1974).

${ }^{10}$ The "Communitas" that Turner defines and discusses (op. cit.) is a close analogue. See also Huizinga (op cit., pp. 1-27, 119-135), and Harvey Cox, The Feast of Fools (Cambridge, Mass.: Harvard University Press, 1969), pp. 3-26, 71-75; also Carl Kerenyi, The Religions of the Greeks and Romans (New York: Dutton, 1962). 
"doing our thing") that has a festival or ritual structure of its own. We forego for an instant, or for an extended holiday, our privacy and the discretions and calculated obligations that go with privacy. We relinquish our right to demur, knowing that to hold back will endanger the moment.

I do not mean, of course, that the experience of the implicit audience to a poem is necessarily one of abandon in the mode just described. On the contrary, the more usual experience is mixed and complex. I believe, however, that Dylan Thomas' achievement was to bring the implicit audience about as close as possible to the sense that both they and he had been caught up into an unleashed whirl of metonymy, charged with the richest possibilities for undiscovered vision, and that if we were to take Thomas, for instance, in his solemn as well as in his mirthful vein, as an anchor point for charting one of the great areas of experiential possibilities within a poetics of performance, then there is clearly another anchor point to be sought, still within the poetics of performance. That is, there are poetic events among the works of Lowell and Frost (and others) that involve performer (if we are still going to want to call him that) and audience in a processive relationship that is altogether different from festivitas and that does not involve being caught up into the dynamic structure of metaphoric or metonymic co-discovery. Instead of release there is restraint. Instead of invitations to the audience's creative imagination there are implied caveats, frustrations and evasions. Most of all there is the invoking of what I want to call privilege.

Privilege is privacy. I mean to use the word, in what follows, in an extended and metaphorical sense derived from its meaning as a legal term. Communications between attorney and client are privileged and may not be used in evidence unless the privilege is mutually relinquished. Communications between penitent and confessor are held under indissoluble privilege. (And here we begin to return by a different route to the implications of calling Lowell's poetry "confessional.") Communications between husband and wife are a trickier matter; but neither may be compelled to testify against the other. And so on. The law pursues its own rough consistency. But for the rest of us, outside the courtroom, there are subtler, more shifting and mysterious gradations of privilege, whose force we feel running through at least some of our daily conversation. I am asked not to repeat what I am about to be told. Or the teller lowers, and at the same time intensifies, his/her voice, and from that I understand that I am about to be entrusted with a confidence that must be kept. It goes further than this. The signals that make me another's trustee, that obligate me to discretion and silence, have various origins and are various in kind. Friends or spouses, having exchanged sufficient signals beforehand, may forego them for a time and never grow uneasy for the privacy of their understanding. Relative strangers, even, may establish lasting rules of privacy, for instance by exchanging vulnerabilities, telling jokes on themselves, thereby invoking the decorum of mutual protection. (The decorum is most clearly sensed when it is violated, a field of serious investigation to Goffman, and of facetious but no less penetrating inquiry to Stephen Potter.) ${ }^{11}$ The protection

\footnotetext{
${ }^{11}$ Stephen Potter, The Theory and Practice of Gamesmansbip; or, The Art of Winning Games without Actually Cheating (New York: H. Holt, 1948).
} 
accorded each other by sensitive people, the privacy signaled for and received, is more than mere confidentiality. What my wife knows about me might, in the mind of one outside our privileged intimacy, seem evidence of shocking fault: a weakness or cruelty or distortion of sensibility. My wife will not only not repeat what she knows, but will also on her own account refrain from jumping to the shocking conclusion. She demurs, gently. A person's survivors are loathe to reveal much to the biographer, often because they know that what is revealed may then become data for the character analysis they themselves were deeply obligated not to conduct. The deeper the privilege, the more it forbids the operation of dissection and analysis.

There is a paradoxical corollary to this, that it is our friends who can (and may) damage us most; and therefore to witness deep fighting is to witness a perverse manifestation of deep friendship. But one may invoke a rule even in the act of violating it; and the rule of privilege is that on the trust of friends rests our confidence that our selves will be allowed to remain intact, whatever dreadful inconsistencies those selves may conceal. And it is in defense of the fragile but necessary self that we even privilege our private meditations. That is, to risk putting it comically, there are things about ourselves that we refuse to tell ourselves, conclusions about ourselves we refuse to draw. We demur. "The evidence is not yet all in," I say, "I am not really the monster I would seem to myself, should I allow myself to look. I shall not look. 'That way madness lies.',

The gestures by which privilege is invoked come in two parts, a request and a reply. We know that while in some cases the two parts are temporally separate from each other (as when Hamlet explicitly requests an answering vow of secrecy before releasing his friends from the night's strange encounter) so in other cases the two parts are so close that one becomes submerged and implicit in the other. Hamlet, donning his suit of madness, confides, "There's n'er a villain dwelling in all Denmark ... but he's an arrant knave," and (subject of course to some stage interpretation) his melancholia implicitly receives the immediate, alarmed, hovering solicitude that the vow is later to solemnize. What happens is that in taking one part, the invoker of privilege assigns his listener the counterpart. The role of despondency requires the answering role of consoler. The role of shame draws forth the role of forgiver. Hurt invokes the healer; and complex hurt requires sometimes a complex and elaborate response to match it. That's plain enough in real life, where the subtlest signal of sorrow, consternation, or pique can throw the close friend or spouse into an acrobatics of compensating maneuver. It should be plain as well in the virtual life we enter in the reading of some poems. As readers we take on roles, indeed roles within roles, according to the implicit signals we sense coming at us out of the fiction or the semi-fiction of poetic encounter. And this taking on of roles, particularly the taking on of the roles of the consoler, forgiver, healer, confessor, or simply friend, may in itself be the centrally significant act. That is, the role-taking itself may constitute the aesthetic reality and total substance of the poetic act, especially when as in the case of Frost and Lowell poem after poem explores the possibilities and impossibilities for love. 
This can look more complex than it feels, of course. The actual reader of Lowell's "Terminal Days at Beverly Farms" might be alerted by the euphemistic title alone to a layering of role-assignment and role-resistance. The poem is a push-pull of implicit requests to feel conflicting sympathies;

At Beverly Farms, a portly, uncomfortable boulder

bulked in the garden's center-

an irregular Japanese touch.

After his bourbon "old fashioned," Father,

bronzed, breezy, a shade too ruddy,

swayed as if on deck-duty

under his six pointed star-lantern-

last July's birthday present.

He smiled his oval Lowell smile,

he wore his cream gabardine dinner-jacket,

and indigo cummerbund.

His head was efficient and hairless,

his newly dieted figure was vitally trim.

Father and Mother moved to Beverly Farms

to be a two minute walk from the station,

half an hour by train from the Boston doctors.

They had no sea-view,

but sky-blue tracks of the commuters' railroad shone

like a double-barrelled shotgun

through the scarlet late August sumac,

multiplying like cancer

at their garden's border.

Father had had two coronaries.

$\mathrm{He}$ still treasured underhand economies,

but his best friend was his little black Chevie,

garaged like a sacrificial steer

with guilded hooves,

yet sensationally sober,

and with less side than an old dancing pump.

The local dealer, a "buccaneer,"

had been bribed a "king's ransom"

to quickly deliver a car without chrome.

Each morning at eight-thirty,

inattentive and beaming,

loaded with his "calc" and "trig" books,

his clipper ship statistics,

and his ivory slide rule,

Father stole off with the Chevie

to loaf in the Maritime Museum at Salem.

He called the curator

"the commander of the Swiss Navy."

Father's death was abrupt and unprotesting.

His vision was still twenty-twenty.

After a morning of anxious, repetitive smiling, 
his last words to Mother were:

"I feel awful." 12

As the poem is about Commander Lowell's death, we must acquire the virtual reader's polite, slightly resisting respect. But the poem is also concerned with the son's constrained, awkward, more-than-slightly-resisting respect toward his father's death. And if our attitude toward the smiling, pathetically mortal father is tense, our attitude toward the satiric and guilty son is far more tense. There is the usual strain for us of fitting ourselves to the moral and emotional outlines of the virtual audience, one who knows Beverly Farms, Boston hospitals, the North Shore, and (at least casually) Commander Lowell himself, as well as the son. Then there is the strain, as virtual audience, of preparing and maintaining a decorous compassion for the dying man. That task is made remarkably harder by the son's emotional misbehavior; for he competes with his father for our sympathy and, because he suffers our strain about the dying man but on a far more intense and intimate level, he both subverts our respect for Commander Lowell and requires that we maintain the respect against himself. We are to be antagonist and sympathizer at once, and really against our will. It is an impossible situaiion, dangerous, like being drawn into a family row, only worse than that because the war between father and son, and within the son, is so completely suppressed and unacknowledged. Nevertheless we are somehow to take sides. The only tangible symbol of our predicament is comical, supplied by the partisan son and hence an impropriety: the "uncomfortable boulder [which] bulked in the garden's center / an irregular Japanese touch."

The "uncomfortable boulder" is inert, but we are not. Neither is Lowell, or his father, dead as he is. Signals on the virtual level are passing among us, signals that do not release or excite, but that constrain and paralyze. The virtual audience's multiple roles grow knotted, in response to and in tight imitation of the knotting of Lowell's role toward his father. In fact we reach a point where all grow inarticulate, father, son, audience, even (almost) the critic in us.

After a morning of anxious, repetitive smiling,

his last words to Mother were:

"I feel awful."

The father demands the last, impossible consolation, yet does so in a kind of leaving, a withdrawing. The son, allowing the father the last word, applies it as a shaming, mortifying rebuke to his own persisting un-love. Yet his contempt even for his father's "anxious, repetitive smiling" lingers as a holdout against the role his father's last signal would require of him. We the unwilling intimates hear confessed the final flaw in the son, his chill and distance, and hear the self-rebuke as a signal to us to respond, somehow, to son Lowell. But son Lowell too ends the poem going away. His leaving of his father's last words last, leaves us. He retreats. And we on our part, virtual audience confided in by the self-despising son, cannot

12From Life Studies (Farrar, Straus \& Giroux, 1959), pp., 73 \& 74. Copyright (C) 1959 by Robert Lowell. Reprinted by permission of Farrar, Straus \& Giroux. 
clearly separate pity from horror, cannot purely take the role of son Lowell's trusted friend, yet cannot reject it either. Finally, the substance of the total poetic act is a tensed, brittle, inarticulate bond, binding Lowell to his father and the audience to Lowell. It is far from comfortable, and perhaps not even ritually expressible. It is altogether dramatic and paradoxical. It is an emotional pulling-in of the audience, at the very moment that it is a communicational close-out.

I mentioned earlier how helpful I had found Bauman's definition of performance as a "situated" activity, which I construe as something one is either clearly inside, or clearly outside, like a game or a joke or a dance-hall. And I mentioned at the same time that I found Bauman's definition a problem when I tried to apply it to certain poems. For there are a great many of Lowell's poems, and some of Frost's, that really don't let you out. "Terminal Days at Beverly Farms" is one of them. In describing any poetic experience one is obviously at first tempted to seek an analogy within art, and that frequently means art as classically conceived: works possessing, above all, the qualities of symmetry, economy, wholeness, and repose. Conceptually, art so thought of is not far from "situated" performance; and Huizinga, retaining an essentially classical notion of art, drew the analogy between play and poetry in such a way that the imaginative activity of a person involved in either is an activity "within," that is within the kinds of boundaries which could be said to surround or frame "situated" performance (pp. 119-135). Richard Poirier has analyzed the contemporary restlessness against this inside-outside conception of the artist's "work," and has tried, through images of process, to supply a new model for the performance activity. ${ }^{13}$ The old model, however, continues despite artistic restlessness to represent a basic fact of most "works." What happens within play or within a poem, as conceived by Huizinga, or within a performance frame, however much it may resemble actuality, belongs to a different or in some way set-apart world. To enter that world is, at least potentially, to enter on a kind of activity that is released from the confinements of physical probability, cause and effect, conservation, and logic. But it is at the same time to enter a fiction, a realm of the counterfeit where consolations, though bright, last only so long, and where even tragedy follows the old patterns and is never quite real. That is, the framed world can be got out of; and even if some writers (especially of contemporary fiction and drama) can so complicate the frames as to bewilder the nervous wanderer with a sense of lost bearings, no virtual audience thinks for a minute (I believe, at least) that the world he has crossed into has actually reversed all metaphor and become the inescapable actuality. We are in, and we can cross out again, sometime. You cannot be playing if you haven't the ability to stop playing.

In "Terminal Days" there is, it seems to me, no such playing, no such crossing cither way. The position of strained obligation in which one is left at the end of the poem is no fiction, and so cannot be left behind. Consequently in order to describe that poetic experience one must have recourse to analogy not with

13Richard Poirier, The Performing Self (New York: Oxford University Press, 1971), pp. 27-61, 86-111. 
framed art, or play, or situated performance, but with patterns of social interaction that are altogether "political," altogether part of the fabric of in-time, gainor-lose, shadow-of-death, one-way living. I sense of course a number of theoretical objections arising to the distinction I am trying to make, the most fundamental being the question whether there is really any such thing as de-situated or un-framed experience, and so whether it really makes any sense to try to separate Lowell's poems from the patterns and strategies of fiction. On the theoretical level I cannot answer, for I do not know. But on the experiential level there are three points we must not overlook. First of all, play, poetry, and the notion of situated performance have meaning for us initially because we feel we can distinguish them from the joys and horrors and complex obligations of quotidian experience. Secondly, "Terminal Days," and a great deal more of Lowell's poetry, requires a virtual audience which feels no break, no passing-over or passing-back, between an outside and an inside of the poetic experience. And finally, a good deal of Lowell's and of Frost's poetry presents a first-person poet-speaker who worries centrally and seriously about the baited trap of fiction, about the temptation to let the poetic image and the laws of play or ritual form take over, about the dangers of a kind of selling-out to art. Frost's no-nonsense couple in "WestRunning Brook" steer each other (a little roughly) away from the fictions of heart and mind and toward the compromises and silence of grown-up, make-do love. Lowell's Dolphin poems fight constantly with the knowledge that, as he puts it in wry overstatement, "Everything is real until it's published." To construe this paradox as a kind of existential challenge is to be ready to follow the artist-critic paper-chase Poirer has outlined for our century (especially in pp. 27-44). But, to some extent at least, Frost and Lowell signal that they are not playing that game, thereby eschewing control of play's fictions.

Lowell's concluding poem in a recent volume pushes the fight against "plotted" expression to a stalemate, less a closure than a gesture of exhaustion;

My Dolphin, you only guide me by surprise,

a captive as Racine, the man of craft,

drawn through his maze of iron composition

by the incomparable wandering voice of Phèdre.

When I was troubled in mind, you made for my body

caught in its hangman's-knot of sinking lines,

the glassy bowing and scraping of my will....

I have sat and listened to too many

words of the collaborating muse,

and plotted perhaps too freely with my life,

not avoiding injury to others,

not avoiding injury to myself-

to ask compassion ... this book, half fiction, an eelnet made by man for the eel fighting-

my eyes have seen what my hand $\operatorname{did} .{ }^{14}$

14Fron The Dolplin (Farrar, Straus \& Giroux, 1973), p. 78. Copyright (C) 1973 by Robert Lowell. Reprinted by permission of Farrar, Straus \& Giroux. 
The poem is a palinode, scrupulously self-trapping. Superficially paraphrased, the last eight lines would suggest that Lowell has entered that vortex, that black-hole of plotted self-scrutiny from which a Burroughs or a Borges emits the highfrequency antic humor of collapsing frames. But resist the arrogant haste to paraphrase, and what comes out of the passage, in fact what is emphatically rendered visually in print, is the blank and pause before the final subdued line. In other words, it is still the shrug of embittered demur, still the signal halfenlisting, half-deflecting compassion, still the knotted, two-way silence, that defines the poetic event.

Privilege halts inquiry, binds the audience to a tensed silence and to an uneasy obligation toward the speaker. A way to feel this is to encounter poems (like the Dolphin sonnet, indeed) where the signalling gesture comes late, or is awkwardly or imperfectly made. The audience may already be underway toward a vicarious, imaginative liminality within the ritual or play context, may already feel its own metaphoric and metonymic powers half released by the performer's dislocation or self-abandonment. To be brought up short at such a moment, to be suddenly assig:ned a conflictingly conservative role, is to experience a strangely affecting split. As audience we sense strongly the direction our initial flight has taken; and when that flight is interrupted by the interposition of a demurring or disclaiming gesture from the speaker, we remain nevertheless aware of the continuation of that flight as a kind of ghostly, unfilled trajectory. The contradiction between that shadow trajectory and our sudden fall, back into the world of calculations and cmbarrassments, provides a tension that is almost Robert Frost's earmark.

In "West-Running Brook," of course, as in Frost's other dialogues, the two semi-fict:ve speakers provide this tension for each other as well as for us; and they are made to spell out in rather large characters the fancies they would hold to did not "matter of fact" intervene. A similar but less explicit dialectic runs through "Directive," wherein, as we imaginatively follow the speaker over the spatial, temporal, and emotional mountain threshold and down to the forgotten spring, an increasingly far fetching flow of symbolic associations is started and restarted, matched with an increasingly self-conscious series of we're-only-pretending disclaimers. The virtual audience is of course largely "within" a set of performance or playing-area frames in this poem; and because we must fictionalize ourselves as taking the hill walk described, with a speaker who at every level is asking us to make-believe the next level, it is only with lingering uncertainty that we suspect, at the end, Frost's inability to sacramentalize the moment;

I have kept hidden in the instep arch

Of an old cedar at the waterside

A broken drinking goblet like the Grail

Under a spell so the wrong ones can't find it,

So can't get saved, as Saint Mark says they mustn't.

(I stole the goblet from the children's playhouse.)

Here are your waters and your watering place.

Drink and be whole again beyond confusion. ${ }^{15}$

${ }^{15}$ From The Poetry of Robert Frost edited by Edwin Connery Lathem, p. 157. Copyright 
The last words are either a flight achieved through the liminality of play-ritual, or they are the shadow of an unfilled trajectory interrupted by the skepticism "now too much for us." If the latter is the case, then the poem does not close so much as it stops. That is, we are left with a speaker to deal with who, in gesturing at what he would say, signals us somewhat sadly not to mind too much his inability to say it. Frost at his forthright best speaks with the telltale accents of the tentative and subjunctive.

$\mathrm{He}$ is at or near his best in the short poem, "Spring Pools," a poem so well wrought imagistically and metrically as to offer superficially the most "set-apart" and self-contained of imaginative excursions. At one of the year's thresholds (how many of Frost's poems are there!) nature seems poised between an old darkness and a new light, yet at the same time between a dying light and a coming darkness. There is a fold-over of symbolic value in the imagery of chill pools and thrusting trees, a fold-over that produces a kind of implicit oxymoron: everything is, for this stilled, inbetween moment, like its opposite. The audience's imagination is freed accordingly from common sense, and launched toward uncommon intuitions of the compelling and the ominous;

These pools that, though in forests, still reflect

The total sky almost without defect,

And like the flowers beside them, chill and shiver,

Will like the flowers beside them soon be gone,

And yet not out by any brook or river,

But up by roots to bring dark foliage on.

Yet in mid-flight, Frost stops us with a self-conscious exaggeration;

The trees that have it in their pent-up buds

To darken nature and be summer woods-

Let them think twice before they use their powers

To blot out and drink up and sweep away

These flowery waters and these watery flowers

From snow that melted only yesterday. ${ }^{16}$

This second stanza is an evasion. I do not mean that derogatorily, except in so far as we should all be derogated for our fears of having our obsessions exposed. Those seem to be Frost's fears, and we must accord him the privilege of his fingerwagging joke; "The trees . . . let them think twice before they use their powers." It is not the trees but Frost who must have second thoughts over where the powers of having "it" may lead. The trees here externalize for the speaker a kind of having whose threat remains covered in quick jest. It is of course the power to obliterate the almost defectless purity of the virgin but life-engendering snowmelt, distillate of almost defectless, recently frozen skies. But the having is more besides, on the level of symbolic potential. In an early spring moment of cyclic

1947 by Robert Frost. Copyright (C) 1964 by Lesley Frost Ballantine. Copyright (C) 1969 by Holt, Rinehart \& Winston. Reprinted by permission of Holt, Rinehart \& Winston, Publishers.

${ }^{16}$ From The Poetry of Robert Frost edited by Edward Connery Lathem, p. 96. Copyright 1928 by Robert Frost. Copyright (C) 1964 by Lesley Frost Ballantine. Copyright (C) 1969 by Holt, Rinehart \& Winston. Reprinted by permission of Holt, Rinehart \& Winston, Publishers. 
change and seasonal promise, when dissipated forces are regathered and concerted toward new birth, the speaker intuits a dark and contrary principle, mysterious and not explored, perhaps vast as a law of being. Whatever it is (and it is my point of course that we are stopped short of seeing it) the speaker tut-tuts at it with half-hearted playfulness, and ravels up the poem into an efficient design of word echoes and internal rhymes. It is not trees that Frost fears, but the revelation of what the trees may symbolically reflect in himself. The tone of the second stanza is a retreat from rapt near-vision ("The trees that have it ...") to selfmocking make-believe ("Let them think twice ...").

I do not mean that the poem loses communicative value by becoming evasive. On the contrary, the evasion adds value on three levels of communication. Most obviously, it is suggestive. As an arm in the motion of throwing suggests a trajectory even if the thrown object is invisible or non-existent, so an image of chill, pure, nourishing pools and darkly transforming tree trunks suggests a metaphoric process we may never be allowed to see explicated for us. We are turned inward rather, upon our own resources; and they lie, as the Freudians tell us, far beneath the censor in us, far beneath that part of us that can "think twice" about the propriety of destructive power. In other words, it is precisely in its not saying just where the images lead that the poem draws us into exploring the dark labyrinth of our own fantasies. On this level of communication Frost's unpursued images work as all successful Romantic images do. The good reader knows that in Frost's silences may lurk an aloof suspiciousness toward the unspeakable. With his sad and growling little dry jest he implies something that is no jesting matter. To say more about it than he says only dilutes its power.

The second level of communication on which the evasion adds value is in the sharing of the joke. Within the frame of Frostian, poetic playfulness, we know a wisecrack when we hear it. And who knows which comes first, the frame or the wisecrack? For the wisecrack, done right, creates the frame; and the play. frame, once we're inside, teaches us to hear the wisecrack. We take part, with the virtual poet, in the nonsense about tyrannical, twice-thinking trees. Frost's poem, like any joke or any utterance that has to be "got," is a symbolic act of solidarity among those who "get it." We form a play conspiracy, as insiders to the game always do. We not only catch the half gesture about the mysteries of having "it," and catch the implication that "it" is somehow a compulsive, obsessive, self-aggrandizing, anti-social power, but we catch as well the mannered little hyperbole by which the speaker tries to wink at us, tries to catch us up into the altogether social, non-obsessive frame of playful make-believe. The paradox of this poem's play is that it is both a formal (or in other words shared, binding) moment, and an opening into chaotic (in other words private, liminal) intuitions. To this extent the poem is a performance in what I believe is the soundest sense of the term.

But finally, Frost's little evasion goes beyond both imagistic suggestiveness, and jest. "There's Frost again," says the jaded reader, "doing his coy, sentiment-witha-joke escape." Other romantics have dared to go so much further, both in catching us up in the set-apart frames of play or song, and in exploring the imagery of 
the demonic. Why is Frost so guarded? But the fact that he is so guarded is a valid and legitimate part of the poetic event. Our mild annoyance seems to say that something is amiss in the performance, if it is mere performance. Accordingly it also throws us into a relationship with Frost that is oddly permanent and inescapable. There is a distinction between "getting" a joke or a truth, and "getting" a confession, since in one case our relationship to the protagonist is only temporary and ficticious, and in the other case it is moral. To "get" Frost's allusion to the Grail in "Directive" one must come within a quasi-liturgical, play community of the make-believe elect. But to "get" the mixture of conviction and uncertainty in his "Here are your waters and your watering place" is to stand in a relationship to him that is far less easy to define in terms of boundaries; one is too close, in a way, to enjoy the immunities of what I called festivitas. Frost is too vulnerable to the implications of his own nervous agnosticism. To "get the point" of a fiction is to be a kind of make-believe insider, and, in so being, imaginatively released. But to "get the point" of a confession is to be emotionally constrained; and if one is also therein an insider, it is in a very different sense. Revellers enjoy one kind of bond, friends another. Frost of course invokes the bond of revellers, often. But he also invokes the bond of friends. Frost's "Spring Pools" may eventually place us within a friend's relationship of patience and forebearance toward the poet, a relationship to which there are no recrossable boundaries. That makes the relationship more than a mere role, more than merely dramatic. It makes it to some extent permanent.

The distinction between reveller and friend may be experienced with immediacy in the reading of Frost's "Provide, Provide"; for the poem, which could be jaunty, picaresque, damn-your-eyes foolery, could alternatively be that truculent, determined deflection of sympathy that is both a signal requesting friendship and a barrier past which the friend is expected to clamber. As social, interactional gesture, the poem has a total perversity, like a lovers' quarrel. It asks for the consolation it cynically refuses to give;

The witch that came (the withered hag)

To wash the steps with pail and rag.

Was once the beauty Abishag,

The picture pride of Hollywood.

Too many fall from great and good

For you to doubt the likelihood.

Die early and avoid the fate.

Or if predestined to die late,

Make up your mind to die in state.

Make the whole stock exchange your own!

If need be occupy a throne,

Where nobody can call you crone.

Some have relied on what they knew;

Others on being simply true.

What worked for them might work for you. 
No memory of having starred

Atones for later disregard,

Or keeps the end from being hard.

Better to go down dignified

With boughten friendship at your side

Than none at all. Provide, provide! ${ }^{17}$

If the reader does not know what to make of the poem it is because she/he does not know whether to hear the poem as a framed fiction of bitterness (and so merely relish its virulence), or whether to hear it as a signal to forego the immunities of make believe, and so move grudgingly and painfully into a kind of permanent and embarrassed apology toward the speaker.

The paradox in both Frost and Lowell is that the most compelling gesture of obligation is the final demur, the turning away into silence. Time after time the implicit subject of their poetry is contact or the failure of contact, love or its transmutation into aggression or malice. And time after time the poem itself is an act, on the part of the virtual poet, aimed at catching the virtual reader in one or another of the infinite and complex nets of permanent relationship. Lowell, addressing many of his Dolphin poems "to Caroline," seems unsure that it can be done. But if the positive gesture towards contact fails, because it fictionalizes and so is a kind of cheating, the negative gesture, the demur or the slight or the testy farewell, remains a kind of hope:

How much less pretentiously, more maliciously

we talk of a close friend to other friends

than shine stars for his festschrift! Which is truer-

The uncomfortable full dress of words for print,

or wordless conscious not even no one ever sees?

The best things I can tell you face to face

Coarsen my love of you in solitary.

See that long lonesome road? It must end

At the will and second of the end-all-

I am still a young man not done running around ....

The great circuit of the stars lies on jewellers velvet;

be close enough to tell me when I will die-

What will love do not knowing it will die?

No telling, no telling ... not even a last choice. ${ }^{18}$

\footnotetext{
17From The Poetry of Robert Frost edited by Edwin Connery Lathem, p. 124. Copyright 1936 by Robert Frost. Copyright (C) 1964 by Lesley Frost Ballantine. Copyright (C) 1969 by Holt, Rinehart \& Winston. Reprinted by permission of Holt, Rinehart \& Winston, Publishers. ${ }^{18}$ From The Dolphin (Farrar, Straus \& Giroux, 1973), p. 67. Copyright (C) 1973 by Robert Lowell. Reprinted by permission of Farrar, Straus \& Giroux.
} 